\title{
Revolução na Terra do Sol
}

Revolution in the Terra do Sol

Marcos Napolitano ${ }^{1}$

${ }^{1}$ Professor do Departamento de História da USP, pesquisador CNPq/PQ, desenvolvendo pesquisa sobre a Guerra Fria e o Golpe de 1964 no Brasil. E-mail: napoli@usp.br 
Resumo: O livro Revolution in the Terra do Sol: the Cold War in Brazil, de Sarah Sarzynski analisa como o contexto da Guerra Fria foi vivida por vários atores culturais e políticos do Nordeste brasileiro entre os anos 1950 e 1960, a partir da categoria tropos, entendida como palavras que são objeto de disputa simbólica e ideológica em contextos específicos.

Palavras-chave: Guerra Fria cultural; Brasil: anos 1960.

\begin{abstract}
Sarah Sarzynski's book Revolution in the Terra do Sol: The Cold War in Brazil examines how the context of the Cold War was experienced by various cultural and political actors in the Brazilian Northeast Region between the 1950s and 1960s, based on the concept of tropos, understood as words that are objects of symbolic and ideological dispute in specific contexts.
\end{abstract}

Keywords: Cultural Cold War; Brazil: 1960s. 
O tema da Guerra Fria cultural vem pautando inúmeras pesquisas nos últimos anos. Nesta perspectiva, o tema saiu do campo estrito da geopolítica e das relações internacionais, focada nos atores estatais das principais potências, para mergulhar nas representações e práticas dos atores sociais e culturais que vivenciaram a época. Em complemento, o recorte da Guerra Fria Global enfatiza a necessidade de se estudar os vários contextos locais e as múltiplas relações ensejadas pela polaridade Ocidente-comunismo, sem cair na armadilha de uma polaridade ideológica absoluta, enquadrada unicamente pelo discurso ideológico das superpotências da época, Estados Unidos e União Soviética.

O livro Revolution in the Terra do Sol: the Cold War in Brazil, de Sarah Sarzynski, dialoga com estas grandes tendências da pesquisa historiográfica recente, analisando como o contexto da Guerra Fria foi vivida por vários atores culturais e políticos do Nordeste brasileiro entre os anos 1950 e 1960. Vale lembrar que, nestas décadas, as contradições sociais e políticas da modernização brasileira se acirraram e incentivaram uma profusão de projetos para o país, que acabaram se enquadrando nos quadros mentais da Guerra Fria Global. O Nordeste brasileiro, por sua vez, principalmente após a Revolução Cubana, se tornou o epicentro das ações e preocupações da esquerda e da direita, pois era visto como a região que iria ser a “próxima Cuba” nas Américas. Nesta linha, o livro de Sarzynski dialoga com a obra de Joseph Page, A revolução que nunca houve (1972).

O livro se divide em duas partes: "O Nordeste na Guerra Fria” e "Lembrando as ligas camponesas". A primeira parte se constitui de cinco capítulos, cada qual dedicado a um ator em disputa sobre o que representaria o Nordeste e o Nordestino naquele contexto histórico. Depois de uma apresentação geral sobre o tema da revolução no Brasil entre os anos 1950 e 1960, a autora analisa as representações do cangaceiro, coronéis, miseráveis rurais, quilombolas, bem como do messianismo e catolicismo de esquerda. Na segunda parte, o foco se volta para as várias formas de lembrança, vestígios e reminiscências daquela época a partir dos anos 1980. Ambas as partes procuram avaliar as diacronias e apropriações de tropos e imagens do Nordeste e do Nordestino que são, como sabemos, categorias-chave na interpretação sobre as identidades nacionais brasileiras do século XX, suas virtudes, impasses e utopias históricas. Neste processo, identidades subjetivas ligadas à ideia de masculinidade e valentia ganham novos sentidos culturais e políticos, deixando de ser a mera representação do atraso, como tradicionalmente se configuravam no debate brasileiro sobre a modernidade, para se transformarem em virtudes revolucionárias. 
A autora analisa o quanto as imagens do Nordeste violento e atrasado ganharam novas dimensões nas lutas culturais e políticas da Guerra Fria, realizando um exercício criativo e instigante de articulação entre a história regional e a global. Para tal, a autora mobiliza fontes de diversas naturezas e origens: documentos oficiais dos governos brasileiro e estadunidense, jornais e revistas do Brasil e dos Estados Unidos, produções intelectuais da época, fontes da “cultura popular", como filmes, peças de teatro, cordel, canções. A metodologia de análise do material primário entrecruza estas fontes diversas, em um exercício intertextual que sempre tem vantagens e problemas, e por vezes ganha um tom ensaístico que pede e estimula o cotejo com outras leituras e formas de análise mais verticalizadas.

De todo modo, o foco da autora está em analisar as representações do Nordeste e do Nordestino na Guerra Fria, e o quanto estes tropos foram objetos de disputa, servindo-se tanto para defender a Revolução quanto para justificar o Golpe de 1964, na grande batalha da Guerra Fria Global no Brasil. A categoria tropo está ligada às mudanças de sentido, por associação ou substituição, que palavras - no caso Nordeste e Nordestino - ganham em contextos ideológicos, linguísticos e sociais diferenciados. Neste ponto, a obra dialoga com outras perspectivas da história cultural, calcadas no jogo entre representações e apropriações.

O cinema ocupa um lugar importante no livro, mas fica subordinado à estratégia intertextual da autora, o que impede uma análise mais adensada e detalhada dos filmes elencados. Assim, filmes canônicos como Aruanda (Linduarte Noronha, 1960), Ganga zumba (Cacá Diegues, 1964), Deus e o diabo na Terra do Sol (Glauber Rocha, 1964), Os fuzis (Ruy Guerra, 1965) são colocados ao lado de filmes menos conhecidos (e reconhecidos) com Riacho de sangue (Fernando de Barros, 1967). Na parte sobre as memórias do Nordeste durante a Guerra Fria, Cabra marcado para morrer (Eduardo Coutinho, 1984) ganha destaque, como obra de revisão e de memória, a um só tempo. De todo modo, o que se perde em profundidade analítica nos filmes, ganha-se em abrangência e diálogo com outras fontes e categorias extra-fílmicas.

A incorporação destas e outras obras nas bibliografias que orientam a pesquisa e o ensino da história do Brasil podem ampliar a perspectiva, já existente na historiografia feita em português, sobre a necessidade de se entrecruzar política e cultura, bem como o local e o global, na compreensão da Guerra Fria, a partir de um entrecruzamento de fontes que nem sempre dialogam entre si na ótica historiográfica mais convencional. 


\section{Referências}

PAGE, J. A revolução que nunca houve. Rio de Janeiro: Record, 1972.

SARZYNSKI, S. Revolution in the Terra do Sol: the Cold War in Brazil. Stanford, CA: Stanford University Press, 2018.

submetido em: 27 set. 2018 | aprovado em: 21 out. 2018 